\title{
microRNAs: tiny RNA molecules, huge driving forces to move the cell
}

\author{
Shenglin Huang, Xianghuo $\mathrm{He}^{凶}$
}

State Key Laboratory of Oncogenes and Related Genes, Shanghai Cancer Institute, Shanghai Jiao Tong University School of Medicine, Shanghai 200032, China

$\bowtie$ Correspondence: xhhe@shsci.org

Received September 20, 2010 Accepted October 9, 2010

\begin{abstract}
Cell migration or movement is a highly dynamic cellular process, requiring precise regulation that is essential for a variety of biological processes. microRNAs (miRNAs) are a class of tiny non-coding RNA molecules that function as critical post-transcriptional regulators of gene expression. Emerging evidence demonstrates that miRNAs play important roles in cell migration and directly contribute to extracellular matrix (ECM) remodeling, cell adhesion, and cell signalling that controls cell migration by targeting a large number of protein-coding genes. Accordingly, the dysregulation of these miRNAs has been linked to several migration-related diseases. In this review, we summarize and highlight the recent advances concerning the roles and validated targets of miRNAs in the control of cell movement.
\end{abstract}

\section{KEYWORDS microRNA, cell migration, metastasis}

\section{INTRODUCTION}

Cell migration or movement is essential for a variety of biologic processes, such as embryonic morphogenesis, wound healing, immune response, and cancer metastasis (Lauffenburger and Horwitz, 1996). It is a highly dynamic phenomenon that requires the precise regulation and integration of multiple signaling pathways (Ridley et al., 2003; Friedl and Wolf, 2010). The initial response of a cell to a migration-promoting agent involves polarization and the formation of a protrusion in the direction of migration (Parent and Devreotes, 1999). Next, the adhesion receptors bind to the extracellular matrix (ECM) or adjacent cells, forming links to the actin cytoskeleton. These adhesions serve as traction points for migration but also stabilize the protrusion via structural connections to actin filaments. Finally, the adhesions disassemble at the cell rear, which allows the cell to detach and contract, thus pulling the cell forward. In the past decades, great progress has been made in understanding the complexities and subtleties of the molecular mechanisms of cell migration. These works mainly focused on investigating the proteins that regulate cell migration. Recently, a growing number of reports have described a new class of small noncoding RNA molecules termed microRNAs (miRNAs) that are involved in cell migration.

miRNAs are evolutionarily conserved non-coding small RNA molecules that function as critical post-transcriptional regulators of gene expression (Bartel, 2004, 2009). They were first discovered in Caenorhabditis elegans (Lee et al., 1993). In human cells, there are about 1000 miRNAs that collectively regulate the expression of more than $30 \%$ of protein-coding genes (Bentwich et al., 2005; Friedman et al., 2009). miRNAs are initially transcribed as long primary transcripts (pri-miRNAs) by RNA polymerase II in the nucleus, which are subsequently cleaved by Drosha into the stem loop structured precursor miRNAs (pre-miRNAs) (Lee et al., 2004). The pre-miRNAs are then exported to the cytoplasm, where they are further processed by the RNase III enzyme Dicer into mature miRNAs (Murchison and Hannon, 2004; Gregory et al., 2006; Ji, 2008). In the cytoplasm, mature miRNA molecules associate with the RNA-induced silencing complex (RISC) and regulate gene expression primarily through binding to the $3^{\prime}$ un-translated regions (UTRs) of target mRNAs (mRNAs), resulting in mRNA degradation or the blockade of mRNA translation (Rana, 2007).

Since miRNAs were discovered, they have been shown to play fundamental roles in a variety of physiologic and pathological processes (He and Hannon, 2004; EsquelaKerscher and Slack, 2006). A growing body of evidence has documented that miRNAs are involved in the control of cell 
movement and directly contribute to ECM remodeling, cell adhesion, and cell signaling during cell migration. This review summarizes and highlights the recent advances in understanding miRNAs and their validated targets underlying cell movement.

\section{miRNAs AND EXTRACELLULAR MATRIX REMODELING}

The extracellular matrix (ECM) is a complex structural entity that is composed of three major classes of biomolecules: structural proteins (e.g., collagens and elastin), specialized proteins (e.g., fibrillin, fibronectin, and laminin), and proteoglycans. The ECM serves as the structural and molecular scaffold for cell adhesion and migration. An increasing number of miRNAs are being identified as upstream regulators of the ECM-related genes that thereby regulate ECM remodeling and influence the mode and efficiency of cell migration (Fig. 1). Two miRNAs, let-7g and miR-29c, were found to directly target the expression of collagen, which is the major protein comprising the ECM. There are at least 30 different collagen genes dispersed throughout the human genome. These genes generate proteins that combine in a variety of ways to create over 20 different types of collagen fibrils. Let-7g was reported to be present at significantly lower levels in metastatic hepatocellular carcinomas (HCCs) and may inhibit $\mathrm{HCC}$ cell migration by targeting type I collagen a2 (COL1A2) (Ji et al., 2010). miR-29c, which is remarkably downregulated in nasopharyngeal carcinomas (NPCs), can target multiple collagens (collagen 1A1, 1A2, 3A1, 4A1, 4A2,
15A1) and laminin 1 (Sengupta et al., 2008). In addition, miR335 can target the progenitor cell transcription factor SOX4 and the extracellular matrix component tenascin $C$ to suppress breast cancer cell migration and metastasis (Tavazoie et al., 2008). The upregulation of miR-128 inhibits Reelin and DCX expression and reduces neuroblastoma cell motility and invasiveness (Evangelisti et al., 2009). Reelin, a high-molecular-weight secreted glycoprotein, is thought to act as a guide for migratory neurons via interactions with two cell surface receptors, the very low density lipoprotein receptor (VLDLR) and the apolipoprotein E receptor 2 (ApoER2); it then triggers a tyrosine kinase signaling cascade. miR-143, induced by myocardin, attenuates ECM versican protein expression and inhibits smooth muscle cell (SMC) migration (Wang et al., 2010b). Versican is a chondroitin sulfate proteoglycan within the ECM that is produced by synthetic SMCs and promotes SMC migration and proliferation. miR143 can also promote $\mathrm{HCC}$ cell invasion and metastasis by repressing the expression of fibronectin type III domain containing 3B (FNDC3B) (Zhang et al., 2009). Fibronectin and the fibronectin type III domain containing 3A (FNDC3A) are two targets that are repressed by miR-17, which can decrease cell adhesion, migration and proliferation (Shan et al., 2009). Transgenic mice overexpressing miR-17 showed overall growth retardation, smaller organs and greatly reduced hematopoietic cell lineages.

Some miRNAs can also regulate the expression of ECM modulators, such as matrix metalloproteinases (MMPs) and tissue inhibitors of metalloproteinases (TIMPs). miR-146b inhibits cell migration and the invasion of glioblastoma cells by

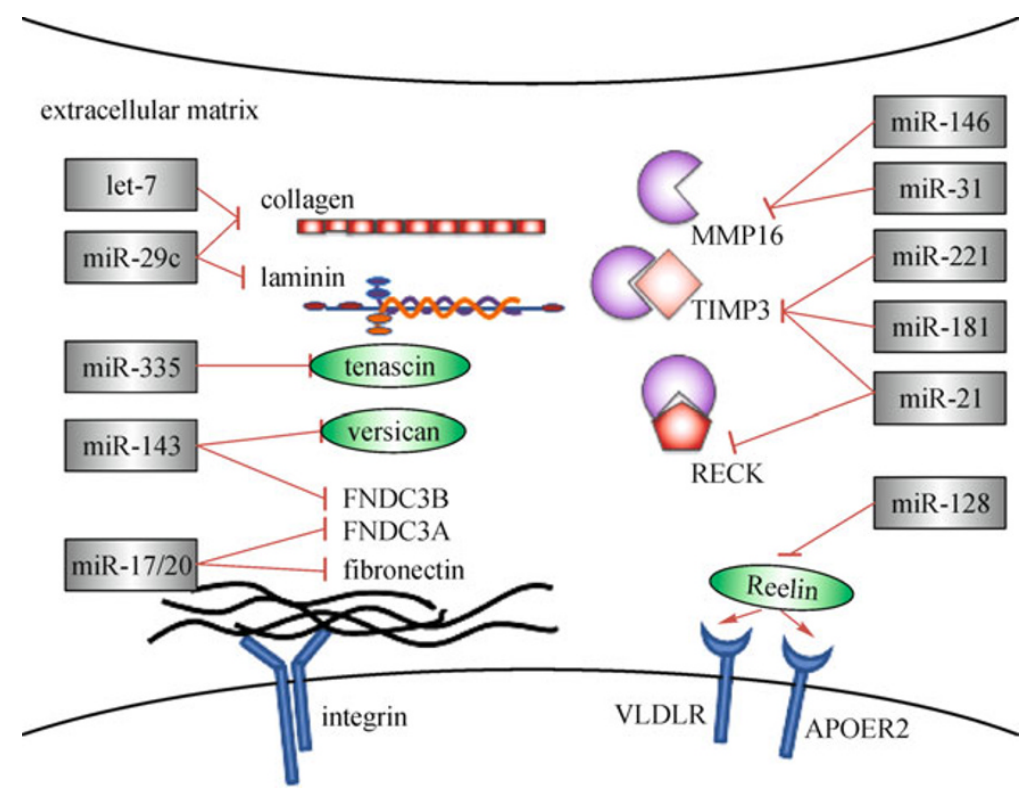

Figure 1. miRNAs and extracellular matrix (ECM) remodeling. miRNAs are identified as upstream regulators of ECM-related genes. FNDC3A: fibronectin type-III domain containing 3A; FNDC3B: fibronectin type III domain containing 3B; MMP: matrix metalloproteinases; TIMP: tissue inhibitors of metalloproteinases; VLDLR: very low density lipoprotein receptor; ApoER2: apolipoprotein E receptor 2. 
reducing the expression of MMP16 (Xia et al., 2009). MMP16 was found to possess proteolytic activity against ECM components, such as type III collagen. MMP16 was also identified as a functional target of miR-31, which can suppress breast tumor cell metastasis (Valastyan et al., 2009). On the other hand, miR-21 contributes to glioma malignancy by downregulating RECK and TIMP3 matrix metalloproteinase inhibitors, which leads to the activation of MMPs, thus promoting the invasiveness of cancer cells (Gabriely et al., 2008). miR-221 and miR-222 also directly regulate the expression of the protein phosphatase $2 \mathrm{~A}$ subunit B (PPP2R2A) and TIMP3 tumor suppressors (Garofalo et al., 2009), leading to the activation of the AKT pathway and metallopeptidases to promote $\mathrm{HCC}$ cell invasion and metastasis. TIMP3 is also a functional target of miR-181b that is induced by TGF- $\beta$ and enhances MMP2 and MMP9 activity by modulating TIMP3 levels and promoting migration and invasion of HCC cells (Wang et al., 2010a).

\section{miRNAs AND CELL ADHESION}

Cell adhesion is mediated by adherent junction proteins, including cadherins, integrins, and other cell adhesion molecules. These proteins can directly or indirectly connect to actin and/or intermediate filament cytoskeleton and thereby provide mechanically robust but dynamic coupling. Recent reports have shown that some miRNAs can modulate these adherent junction genes. It was recently reported that miR-9 can directly target $\mathrm{CDH} 1$, the E-cadherin-encoding mRNA, leading to increased cell motility and invasiveness in breast cancer cells (Ma et al., 2010). In both morphogenesis and cancer models, the loss of E-cadherin results in weakened cell junctions followed by cell detachment and the onset of a single-cell mode of migration. This is termed the epithelialmesenchymal transition (EMT). EMT describes the molecular reprogramming and phenotypic changes characterizing the conversion of polarized immotile epithelial cells to motile mesenchymal cells. This process allows the remodeling of tissues during embryonic development and is implicated in the promotion of tumor invasion and metastasis. miR-9 can suppress the expression of E-cadherin to promote carcinoma cell motility and invasiveness and to activate $\beta$-catenin signaling. The latter contributes to an elevated expression of VEGFA, leading to the induction of tumor-associated angiogenesis. In addition, the loss of expression of miR-200 family members has been shown to play a critical role in the repression of E-cadherin by ZEB1 and ZEB2 during EMT, enhancing cancer cell migration and invasion (Korpal et al., 2008).

Integrins are a major family of cell-cell and cell-ECM adhesion proteins. Integrins contribute to cell-cell cohesion indirectly through intercellular ECM components, such as the binding of $\alpha 5 \beta 1$ integrin to intercellular deposits of fibronectin and the binding of $\alpha 6 \beta 1$ integrin to intercellular laminin. In addition to this adhesive function, integrins are also involved in intracellular signaling and the regulation of cytoskeletal formation and play important roles in promoting cell migration. Each integrin consists of non-covalently linked $\alpha$ and $\beta$ subunits. Integrin $\beta 1$ (ITGB1) was recently shown to be directly regulated by miR-183 (Li et al., 2010). The regulation of ITGB1 expression by miR-183 provides a new mechanism for the anti-metastatic role of miR-183 and suggests that this miRNA could influence the development and function of neurosensory organs and contribute to functional alterations associated with cellular senescence in human diploid fibroblasts and human trabecular meshwork cells. In addition to ITGB1, miR-183 was also found to target KIF2A, a kinesin essential for both bipolar spindle assembly and chromosome movement (Li et al., 2010).

miRNAs can also directly regulate other cell adhesion molecules, such as CD117 and CD44. CD44, the receptor for hyaluronic acid (HA), was identified as a functional target of miR-373 and miR-520c, which can stimulate breast cancer cell migration and invasion (Huang et al., 2008). CD44 mediates cell-cell and cell-matrix interactions through its affinity for HA and plays an important role in cell migration, tumor growth, and progression. CD44 is also directly targeted by miR-328, which regulates zonation morphogenesis (Wang et al., 2008a). CD117 (c-kit) is the receptor for the cytokine stem cell factor (SCF) and plays a key role in endothelial progenitor cell migration and homing. miR-221, a specific miRNA identified in human umbilical vein endothelial cells (HUVECs), affects the expression of c-kit and participates in the regulation of angiogenesis (Poliseno et al., 2006). Under hyperglycemic conditions, miR-221 is induced in HUVECs, which consequently triggers inhibition of c-kit and impairment of HUVEC migration (Li et al., 2009c). Downregulation of miR221 can attenuate high-glucose-induced suppression of c-kit and migration in HUVECs.

\section{miRNAs AND CELL SIGNALING OF CELL MIGRATION}

\section{miRNAs and HGF/c-Met signaling}

The hepatocyte growth factor (HGF)/c-Met signaling cascade is considered to be involved in embryonic organ development, adult organ regeneration, wound healing, and tumor metastasis. HGF interacts with the proto-oncogenic c-Met receptor tyrosine kinase and regulates cell growth, cell motility, and morphogenesis. Recently, c-Met has been shown to be directly regulated by miR-1, miR-206, miR-34a, miR-23b, and miR-199a-3p (Fig. 2). miR-1 and miR-206, highly expressed in skeletal muscles, can suppress c-Met expression and inhibit cell proliferation and migration of rhabdomyosarcoma (Yan et al., 2009). miR-34a decreased cMet-induced phosphorylation of extracellular signal-regulated kinases 1 and 2 (ERK1/2) and inhibited HCC cells migration 


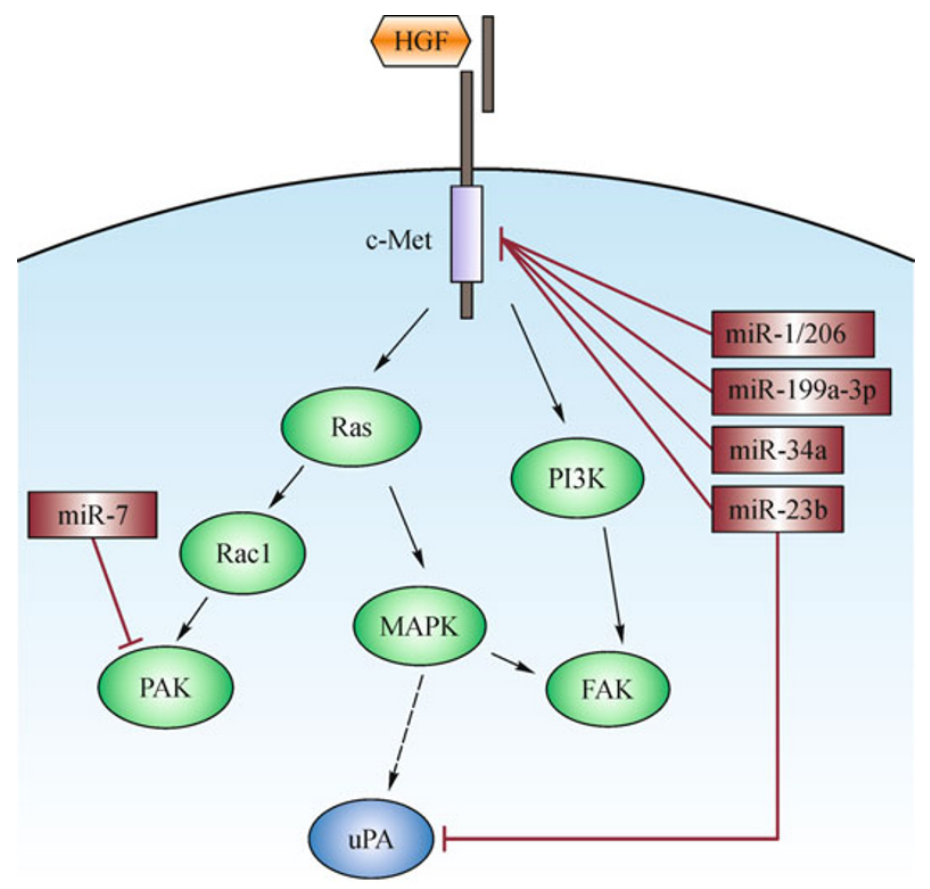

Figure 2. miRNAs and hepatocyte growth factor (HGF)/c-Met signaling. HGF interacts with the proto-oncogenic c-Met receptor tyrosine kinase and regulates cell growth, cell motility, and morphogenesis. The c-Met mRNA level has been shown to be directly regulated by miR-1, miR-206, miR-34a, miR-23b, and miR-199a-3p. PAK, p21-activated kinase; uPA: urokinase-type plasminogen activator; PI3K: phosphatidylinositol 3-kinase; FAK: focal adhesion kinase.

and invasion ( $\mathrm{Li}$ et al., 2009a). miR-23b decreased the proliferation and migration abilities of HCC cells by inhibiting c-Met and urokinase-type plasminogen activator (UPA) (Salvi et al., 2009). The latter is a critical functional downstream target of HGF/c-Met signaling. miR-199a-3p reduced HCC cells invasive capability by targeting c-Met and mTOR (Fornari et al., 2010). In addition, miR-101, a miRNA that is repressed in $\mathrm{HCC}$, downregulated the expression of the fos oncogene, thereby reducing HGF-induced cell invasion and migration (Li et al., 2009b).

\section{miRNAs and epidermal growth factor receptor (EGFR) signaling}

The epidermal growth factor receptor (EGFR) belongs to the ERBB family of receptor tyrosine kinases, which consists of four members: EGFR (ErbB1, HER1), ErbB2 (HER2), ErbB3 (HER3), and ErbB4 (HER4). ErbB2 is a unique member of the ErbB family because it does not bind any of the known ligands with high affinity, but it is the preferred heterodimeric partner for other EGFRs. These receptors couple binding of extracellular growth factor ligands to intracellular signaling pathways and regulate diverse responses, including proliferation, differentiation, and cell motility. miRNAs have been shown to directly regulate the expression of these receptors (Fig. 3). The regulation of miR-146a by breast cancer metastasis suppressor 1 (BRMS1) can suppress breast cancer cell migration and metastasis by targeting the expression of EGFR (Lin et al., 2008). The overexpression of miR-125a or miR-125b reduced ERBB2 and ERBB3 at both the transcript and protein level in these cells, leading to reduced ERK $1 / 2$ and AKT signaling (Scott et al., 2007). Functionally, miR125a- or miR-125b-overexpressing SKBR3 cells displayed markedly reduced cell migration and invasion capacities. Intriguingly, miR-125 was shown to be significantly downregulated upon EGF stimulation (Wang et al., 2009). Thus, the EGF-miR-125- ERBB2/3 axis may be a positive feedback loop for EGFR signaling.

\section{miRNAs and PI3K signaling}

Phosphatidylinositol 3-kinase ( $\mathrm{PI} 3 \mathrm{~K}$ ) signaling plays an important role in the regulation of cell migration and particularly in controlling the polarity of migrating cells. The $\mathrm{PI} 3 \mathrm{~K}$ signaling cascade can be stimulated by EGF. The activation of this pathway increases the activity of the AKT kinase, which can phosphorylate mTOR (mammalian target of rapamycin). The PI3K/AKT pathway is controlled by the tumor suppressor lipid phosphatase PTEN. Recently, PTEN was identified as a direct target of miR-21, miR-221, and miR222. Aberrant expression of miR-21 cannot only contribute to $\mathrm{HCC}$ growth but can also mediate HCC cell invasion by directly targeting PTEN (Meng et al., 2007). miR-21 can alter focal adhesion kinase (FAK) phosphorylation and the 


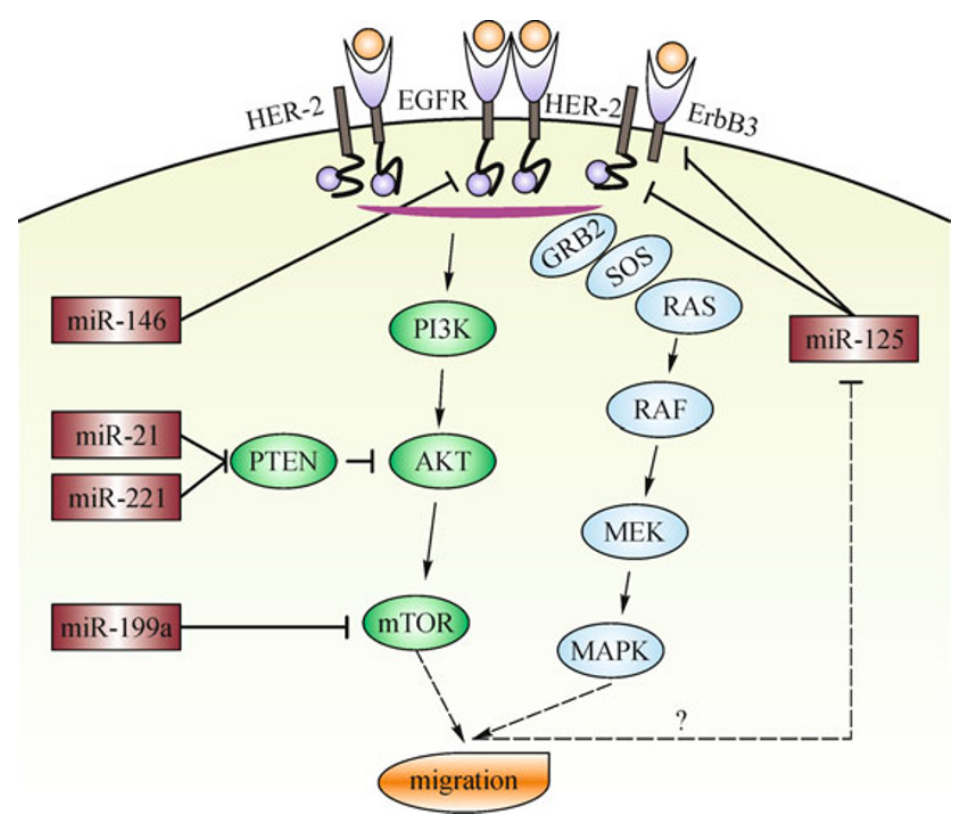

Figure 3. miRNAs and EGFR signaling. The epidermal growth factor receptors (EGFRs) belong to the ERBB family of receptor tyrosine kinases. HER2 (ErbB2) is a unique member of the ErbB family because it does not bind any of the known ligands with high affinity, but it is the preferred heterodimeric partner for other EGFRs. These receptors couple the binding of extracellular growth factor ligands to intracellular signaling pathways and regulate diverse responses, including proliferation, differentiation, and cell motility. MiRNAs have been shown to directly regulate the expression of these receptors. PTEN: phosphatase and tensin homolog; mTOR: mammalian target of rapamycin.

expression of the matrix metalloproteases MMP2 and MMP9, both downstream mediators of PTEN involved in cell migration and invasion. PTEN was also found to be the direct target of miR-221 and miR-222, which induce TRAIL resistance and enhance HCC cell migration. Recently, mTOR was identified as a target of miR-199a-3p, which can block the G1-S transition and reduce HCC cell invasion (Fornari et al., 2010). In addition, the DNA damage-inducible transcript 4 (DDIT4), a modulator of the mTOR pathway, was also found to be a target of miR-221 and miR-222 (Pineau et al., 2010).

\section{miRNAs and Rho GTPases signaling}

The Rho GTPases signaling cascade plays a central role in regulating cell adhesion, migration, and cytoskeletal reorganization. The Rho family of GTPases is a family of small signaling $G$ proteins and is a subfamily of the Ras superfamily. In mammals, Rho GTPases contain about 20 members, which are largely divided into the Cdc42, Rac1, and Rho (RhoA, RhoB, and RhoC) subfamilies. The activity of Rho GTPases is tightly controlled by several families of regulators, including guanine nucleotide exchange factors (GEFs), GTPase-activating proteins (GAPs), and Rho GDPdissociation inhibitor (RhoGDI). Rho GTPases carry out distinct functions by activating various downstream effectors, such as Rho-associated kinases (ROCK) and p21-activated kinases (PAK). A growing body of evidence shows that miRNAs can affect cell migration by regulating expression of the Rho GTPase members, their effectors and their regulators (Fig. 4). For example, miR-31 can directly target Rho A, which is involved in the inhibition of several steps of breast cancer cell metastasis, including local invasion, extravasation, initial survival at a distant site, and metastatic colonization (Valastyan et al., 2009). miR-10b is highly expressed in metastatic breast cancer cells and positively regulates cell migration and invasion. miR-10b proceeds to inhibit translation of the mRNA encoding homeobox D10, resulting in increased RhoC expression (Ma et al., 2007). RhoC was identified as a functional target of miR-138, which suppresses tongue squamous cell carcinomas (TSCC) cell migration and invasion. Furthermore, miR-138 can directly regulate the expression of the Rho-associated kinase ROCK2, a downstream signaling molecule of RhoC. By concurrently targeting RhoC and ROCK2, miR-138 leads to the reorganization of the stress fibers and the subsequent cell morphology change to a round bleb-like shape as well as the suppression of cell migration and invasion (Jiang et al., 2010). In addition, ROCK1 was substantially suppressed by miR-146a, which was decreased in hormone-refractory prostate carcinomas (HRPCs) and reduced cell invasion and metastasis to human bone marrow endothelial cell monolayers (Lin et al., 2008). Ezrin and stathmin are the effectors of ROCK and are also found to be regulated by miRNAs. Ezrin is a target of 
miR-183, which has been reversely correlated with the metastatic potential of lung cancer cells and inhibits migration and invasion in lung cancer cells (Wang et al., 2008b). miR-9 was shown to promote proliferation but to suppress the migration of human neural progenitor cells (hNPCs) by directly downregulating the expression of stathmin (Delaloy et al., 2010), which increases microtubule instability. miR-7 introduction inhibits the motility, invasiveness, anchorageindependent growth, and tumorigenic potential of highly invasive breast cancer cells by directly targeting p21activated kinase 1 (PAK1) expression (Reddy et al., 2008). PAK1 is a critical effector that links Cdc42 and Rac to cytoskeletal reorganization and nuclear signaling. miRNAs can also modulate regulators of Rho GTPases. miR-151, a frequently amplified miRNA on chromosome $8 q 24$, increases HCC cell migration and invasion by directly targeting RhoGDIA (Ding et al., 2010). RhoGDIA can prevent nucleotide exchange and membrane association of Rho GTPases and thus block their activation. Moreover, miR-151 can function synergistically with the host gene FAK to enhance HCC cell motility and spreading.

\section{miRNAS AND OTHER REGULATORS OF CELL MIGRATION}

miRNAs can also target other migration-related genes including chemokine (IL8), cell surface proteins (ADAM10, ADAM17, Ephrin-A3, and LRP1), adapter proteins (Crk and GNAI2), and transcription factors (Pax3, Pax7, MTA1, c-Myb,
FOXO3, and Mitf-M). miR-17/20 directly represses chemokine IL8 expression and inhibits cellular invasion and tumor metastasis of breast cancer (Yu et al., 2010). miR-122 was shown to inhibit HCC cell metastasis by directly targeting the expression of ADAM10 and ADAM17 (Bai et al., 2009; Tsai et al., 2009), which are cell surface proteins with a unique structure, possessing both potential adhesion and protease domains. miRNA-210 modulates the endothelial cell response to hypoxia and inhibits the receptor tyrosine kinase ligand ephrin-A3 (Fasanaro et al., 2008). miRNA-205 inhibits tumor cell migration by downregulating the expression of the LDL receptor-related protein 1 (LRP1) (Song and Bu, 2009). miRNA-126 inhibits invasion in non-small cell lung carcinoma cell lines by the repression of adapter protein Crk expression (Crawford et al., 2008). miR-30d can enhance intrahepatic and distal pulmonary metastasis of HCC cells by repressing the expression of Galphai2 (GNAI2) (Yao et al., 2010). The transcription factors related to cell migration were also identified as functional targets of miRNAs. miR-27b regulates $\mathrm{Pax} 3$ protein levels, and this downregulation ensures rapid and robust entry into the myogenic differentiation program and inhibits progenitour cell migration (Crist et al., 2009). miR-196 was shown as an essential regulatour of tail regeneration by targeting the expression of BMP4 and Pax7 (Sehm et al., 2009). miR-661 inhibited the motility, invasiveness, and tumorigenicity of invasive breast cancer cells by downregulating the expression of metastatic tumor antigen 1 (MTA1) (Reddy et al., 2009). miR-150 effectively reduced $\mathrm{c}-\mathrm{Myb}$ expression and enhanced cell

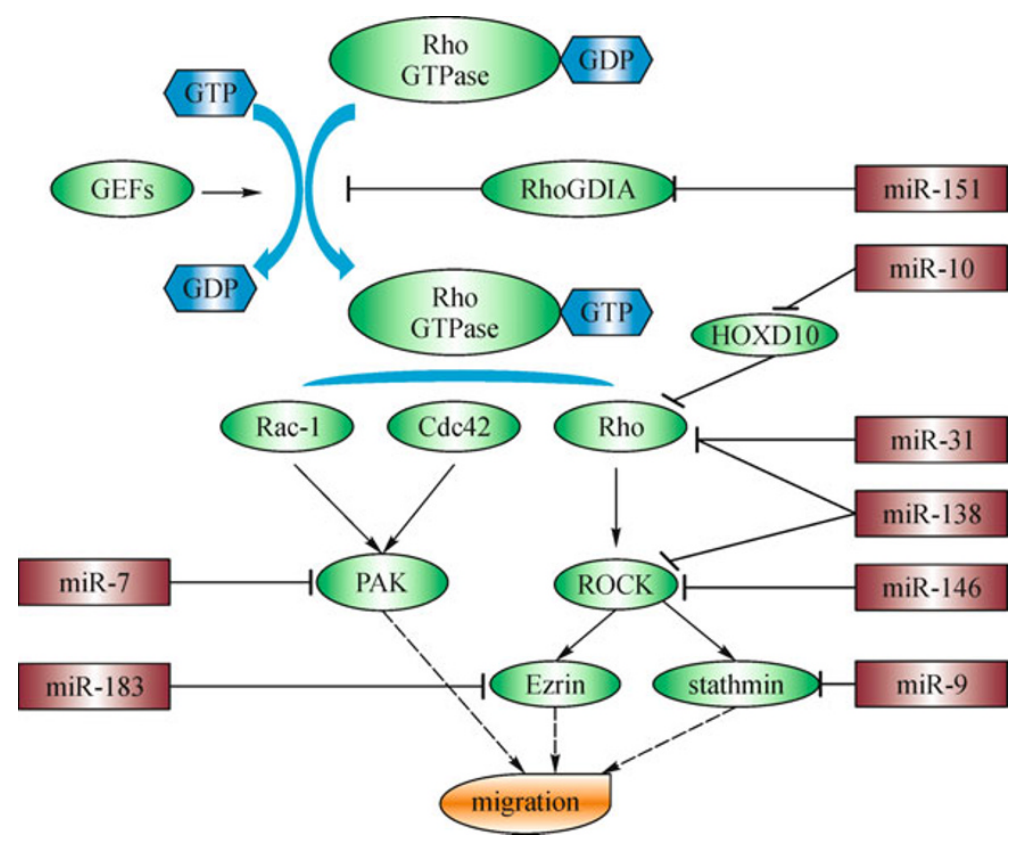

Figure 4. MiRNAs and Rho GTPases. The Rho GTPases signaling cascade plays a central role in regulating cell adhesion, migration, and the cytoskeleton. MiRNAs can affect cell migration by regulating the expression of the Rho GTPases members as well as their effectors and regulators. GEFs: guanine nucleotide exchange factors; RhoGDIA: Rho GDP-dissociation inhibitor; ROCK: Rho-associated kinases; PAK: p21-activated kinases; HOXD10: homeobox D10. 
migration in HMEC-1 cells (Zhang et al., 2010). Aberrant miR-182 expression promotes melanoma metastasis by repressing $\mathrm{FOXO} 3$ and microphthalmia-associated transcription factor-M (Mitf-M) (Segura et al., 2009). miR-10b promotes cell migration and invasion by downregulating the expression of KLF4 in human esophageal cancer cells (Tian et al., 2010).

\section{CONCLUSION}

Current research shows that many miRNAs have significant roles in the driving forces of cell movement by directly targeting a large number of critical migration-related genes. These miRNAs and their target mRNAs construct a complex interacting network controlling cell movement. As shown in Table 1, some miRNAs have been shown to target multiple genes involved in cell migration. For example, miR-17/20 can target IL-8, CXCL1, CK8, fibronectin, and FNDC3A, and miR221 can target PTEN, TIMP3, DDIT4, and c-kit. As these target genes are all involved in cell migration, individual miRNAs thus have robust roles in cell migration by concurrently regulating their corresponding target genes. Conversely, a single gene may be modulated by multiple miRNAs. As shown in Table 1, c-Met, PTEN, MMP16, and TIMP3 have been found to be regulated by at least two miRNAs. Note that some miRNAs (miR-9 and miR-221) have dual roles in their effect on cell migration. For example, miR-9 can increase breast cancer cell motility and invasiveness by targeting $\mathrm{CDH} 1$, the E-cadherin-encoding mRNA, whereas miR-9 is shown to suppress the migration of human neural progenitor cells (hNPCs) by downregulating the expression of stathmin. This heterogeneity may result from the divergent cell types and subsequent different target genes. In conclusion, the discovery of miRNAs and their corresponding targets is a new field that allows for the investigation of the underlying molecular mechanisms of cell movement and for the development of therapies for the treatment of migrationrelated disorders.

Table 1 The miRNAs and the validated targets in the driving forces of cell migration

\begin{tabular}{|c|c|c|c|c|c|}
\hline$\overline{\text { miRNA }}$ & regulation & targets & migration & function & references \\
\hline Let-7 & - & COL1A2 & - & inhibits HCC cell migration & Ji et al., 2010 \\
\hline $\mathrm{miR}-1 / 206$ & - & c-Met & - & $\begin{array}{c}\text { inhibits rhabdomyosarcoma } \\
\text { development }\end{array}$ & Yan et al., 2009 \\
\hline miR-10b & twist & HOXD10, Tiam1, Rac1, KLF4 & + & $\begin{array}{c}\text { promotes cell migration and inva- } \\
\text { siveness in breast cancer, glioma, } \\
\text { and squamous cell carcinoma } \\
\text { cells }\end{array}$ & $\begin{array}{l}\text { Ma et al., 2007; } \\
\text { Tian et al., } 2010\end{array}$ \\
\hline miR-101 & - & FOS & - & Inhibits HCC cell invasion & Li et al., 2009b \\
\hline $\operatorname{miR}-122$ & - & ADAM10, ADAM17 & - & $\begin{array}{c}\text { inhibits HCC cell migration and } \\
\text { metastasis }\end{array}$ & $\begin{array}{l}\text { Bai et al., 2009; } \\
\text { Tsai et al., } 2009\end{array}$ \\
\hline miR-125 & EGFR regulated & ErbB2/3 & - & $\begin{array}{c}\text { inhibits cell migration and invasion } \\
\text { in breast cancer and lung cancer } \\
\text { cells }\end{array}$ & $\begin{array}{l}\text { Scott et al., 2007; } \\
\text { Wang et al., } 2009\end{array}$ \\
\hline miR-126 & - & Crk & - & $\begin{array}{l}\text { inhibits lung cancer cell migration } \\
\text { and invasion }\end{array}$ & Crawford et al., 2008 \\
\hline miR-128 & - & Reelin, DCX & - & $\begin{array}{l}\text { inhibits neuroblastoma cell motility } \\
\text { and invasiveness }\end{array}$ & Evangelisti et al., 2009 \\
\hline $\operatorname{miR}-138$ & - & RhoC, ROCK2 & - & $\begin{array}{c}\text { inhibits tongue squamous cell } \\
\text { carcinoma cell migration and } \\
\text { invasion }\end{array}$ & Jiang et al., 2010 \\
\hline miR-143 & NF-kB, myocardin & Versican, FNDC3B & - & $\begin{array}{l}\text { inhibits smooth muscle cells } \\
\text { migration }\end{array}$ & $\begin{array}{l}\text { Wang et al., 2010b; } \\
\text { Zhang et al., } 2009\end{array}$ \\
\hline $\operatorname{miR}-146$ & BRMS1 & EGFR, MMP16, ROCK1 & - & $\begin{array}{l}\text { inhibits cell migration and invasion } \\
\text { in breast cancer and glioma cells }\end{array}$ & $\begin{array}{l}\text { Lin et al., 2008; } \\
\text { Xia et al., } 2009\end{array}$ \\
\hline miR-150 & - & C-myb & + & $\begin{array}{l}\text { promotes endothelial cell migra- } \\
\text { tion }\end{array}$ & Zhang et al., 2010 \\
\hline miR-151 & amplification & RhoGDIA & + & $\begin{array}{c}\text { promotes } \mathrm{HCC} \text { cell migration and } \\
\text { metastasis }\end{array}$ & Ding et al., 2010 \\
\hline $\mathrm{miR}-17 / 20$ & c-myc & $\begin{array}{c}\text { IL-8, CXCL1, CK8, fibronectin, } \\
\text { FNDC3A }\end{array}$ & - & $\begin{array}{l}\text { inhibits breast cancer cell migra- } \\
\text { tion and metastasis }\end{array}$ & $\begin{array}{l}\text { Shan et al., 2009; } \\
\text { Yu et al., } 2010\end{array}$ \\
\hline
\end{tabular}


(Continued)

\begin{tabular}{|c|c|c|c|c|c|}
\hline miRNA & regulation & targets & migration & function & references \\
\hline miR-181b & TGF- $\beta$ & TIMP3 & + & $\begin{array}{l}\text { promotes } \mathrm{HCC} \text { cell migration and } \\
\text { invasion }\end{array}$ & Wang et al., 2010a \\
\hline miR-182 & amplification & FOXO3, Mitf-M & + & $\begin{array}{l}\text { promotes melanoma cell migra- } \\
\text { tion and metastasis }\end{array}$ & Segura et al., 2009 \\
\hline miR-183 & & Integrin 1 , kinesin 2 , ezrin & - & $\begin{array}{l}\text { inhibits cell migration and invasion } \\
\text { in HeLa and lung cancer cells }\end{array}$ & $\begin{array}{l}\text { Wang et al., } 2008 b \text {; } \\
\text { Li et al., } 2010\end{array}$ \\
\hline miR-196 & & BMP4, Pax7 & - & $\begin{array}{l}\text { inhibits tail regeneration of sala- } \\
\text { manders }\end{array}$ & Sehm et al., 2009 \\
\hline $\operatorname{miR}-199 a-3 p$ & & mTOR, c-Met & - & inhibits HCC cell invasion & Fornari et al., 2010 \\
\hline miR-200 & & ZEB1, ZEB2 & - & $\begin{array}{l}\text { counteracts epithelial-to- } \\
\text { mesenchymal transition and } \\
\text { reduces cell migration/invasion }\end{array}$ & Korpal et al., 2008 \\
\hline miR-205 & & LRP1 & - & inhibits cell migration and invasion & Song and $\mathrm{Bu}, 2009$ \\
\hline miR-21 & & TIMP3, RECK, PTEN & + & $\begin{array}{c}\text { promotes cell migration and inva- } \\
\text { sion in breast cancer, glima, and } \\
\text { HCC cells }\end{array}$ & $\begin{array}{l}\text { Meng et al., } 2007 ; \\
\text { Gabriely et al., } 2008\end{array}$ \\
\hline miR-210 & HIF-1 & Ephrin-A3 & + & $\begin{array}{l}\text { promotes endothelial cell migra- } \\
\text { tion in response to hypoxia }\end{array}$ & Fasanaro et al., 2008 \\
\hline miR-221 & c-jun & PTEN, TIMP3, DDIT4, c-kit & \pm & $\begin{array}{l}\text { promotes migration and metasta- } \\
\text { sis in NSCLC and HCC cells. } \\
\text { Inhibits vascular smooth muscle } \\
\text { cells migration }\end{array}$ & $\begin{array}{l}\text { Garofalo et al., 2009; } \\
\text { Li et al., 2009c; } \\
\text { Pineau et al., 2010; } \\
\text { Poliseno et al., 2006 }\end{array}$ \\
\hline $\operatorname{miR}-23 b$ & - & uPA, c-Met & - & $\begin{array}{l}\text { inhibits HCC cell migration and } \\
\text { invasion }\end{array}$ & Salvi et al., 2009 \\
\hline $\operatorname{miR}-27 b$ & - & Pax3 & - & $\begin{array}{l}\text { regulates myogenic differentiation } \\
\text { and inhibits muscle stem cell } \\
\text { migration }\end{array}$ & Crist et al., 2009 \\
\hline miR-29c & - & Collagens, laminin 1 & - & $\begin{array}{l}\text { inhibits nasopharyngeal carcino- } \\
\text { mas cell migration and metastasis }\end{array}$ & Sengupta et al., 2008 \\
\hline miR-30d & - & Gnail2 & + & $\begin{array}{c}\text { promotes } \mathrm{HCC} \text { cell migration and } \\
\text { metastasis }\end{array}$ & Yao et al., 2010 \\
\hline miR-31 & - & MMP16, RhoA & - & $\begin{array}{l}\text { inhibits cell migration and metas- } \\
\text { tasis in breast cancer cells }\end{array}$ & Valastyan et al., 2009 \\
\hline miR-328 & - & CD44 & + & $\begin{array}{l}\text { regulates zonation morphogen- } \\
\text { esis }\end{array}$ & Wang et al., 2008a \\
\hline miR-335 & - & SOX4, tenascin C & - & $\begin{array}{l}\text { inhibits breast cancer cell migra- } \\
\text { tion and metastasis }\end{array}$ & Tavazoie et al., 2008 \\
\hline miR-34a & - & c-Met & - & $\begin{array}{c}\text { inhibits } \mathrm{HCC} \text { cell migration and } \\
\text { invasion }\end{array}$ & Li et al., 2009a \\
\hline miR-373/520 & - & CD44 & + & $\begin{array}{l}\text { promotes breast cancer cell } \\
\text { migration and metastasis }\end{array}$ & Huang et al., 2008 \\
\hline miR-661 & c/EBPA & MTA1 & - & $\begin{array}{l}\text { inhibits breast cancer cell migra- } \\
\text { tion and invasion }\end{array}$ & Reddy et al., 2009 \\
\hline miR-7 & HoxD10 & PAK1 & - & $\begin{array}{l}\text { inhibits breast cancer cell migra- } \\
\text { tion and invasion }\end{array}$ & Reddy et al., 2008 \\
\hline miR-9 & MYC/MYCN & E-cadherin, stathmin & \pm & $\begin{array}{l}\text { promotes breast cancer cell } \\
\text { migration and metastasis. Inhibits } \\
\text { human neural progenitor cells } \\
\text { migration }\end{array}$ & $\begin{array}{l}\text { Delaloy et al., } 2010 ; \\
\text { Ma et al., } 2010\end{array}$ \\
\hline
\end{tabular}




\section{ACKNOWLEDGEMENTS}

This work was partially supported by the National Natural Science Foundation of China (Grant No. 81071637), the Science and Technology Commission of Shanghai Municipality (Grant No. 10JC1414200), and the Doctoral Program of Higher Education of China (Grant No. 200802480076). We apologize to those colleagues who have contributed to this exciting field but whose work could not be cited because of space limitations.

\section{REFERENCES}

Bai, S., Nasser, M.W., Wang, B., Hsu, S.H., Datta, J., Kutay, H., Yadav, A., Nuovo, G., Kumar, P., and Ghoshal, K. (2009). MicroRNA-122 inhibits tumorigenic properties of hepatocellular carcinoma cells and sensitizes these cells to sorafenib. J Biol Chem 284, 32015-32027.

Bartel, D.P. (2004). MicroRNAs: genomics, biogenesis, mechanism, and function. Cell 116, 281-297.

Bartel, D.P. (2009). MicroRNAs: target recognition and regulatory functions. Cell 136, 215-233.

Bentwich, I., Avniel, A., Karov, Y., Aharonov, R., Gilad, S., Barad, O., Barzilai, A., Einat, P., Einav, U., Meiri, E., et al. (2005). Identification of hundreds of conserved and nonconserved human microRNAs. Nat Genet 37, 766-770.

Crawford, M., Brawner, E., Batte, K., Yu, L., Hunter, M.G., Otterson, G.A., Nuovo, G., Marsh, C.B., and Nana-Sinkam, S.P. (2008). MicroRNA-126 inhibits invasion in non-small cell lung carcinoma cell lines. Biochem Biophys Res Commun 373, 607-612.

Crist, C.G., Montarras, D., Pallafacchina, G., Rocancourt, D., Cumano, A., Conway, S.J., and Buckingham, M. (2009). Muscle stem cell behavior is modified by microRNA-27 regulation of Pax3 expression. Proc Natl Acad Sci U S A 106, 13383-13387.

Delaloy, C., Liu, L., Lee, J.A., Su, H., Shen, F., Yang, G.Y., Young, W. L., Ivey, K.N., and Gao, F.B. (2010). MicroRNA-9 coordinates proliferation and migration of human embryonic stem cell-derived neural progenitors. Cell Stem Cell 6, 323-335.

Ding, J., Huang, S., Wu, S., Zhao, Y., Liang, L., Yan, M., Ge, C., Yao, J., Chen, T., Wan, D., et al. (2010). Gain of miR-151 on chromosome 8q24.3 facilitates tumour cell migration and spreading through downregulating RhoGDIA. Nat Cell Biol 12, 390-399.

Esquela-Kerscher, A., and Slack, F.J. (2006). Oncomirs - microRNAs with a role in cancer. Nat Rev Cancer 6, 259-269.

Evangelisti, C., Florian, M.C., Massimi, I., Dominici, C., Giannini, G., Galardi, S., Buè, M.C., Massalini, S., McDowell, H.P., Messi, E., et al. (2009). miR-128 up-regulation inhibits Reelin and DCX expression and reduces neuroblastoma cell motility and invasiveness. FASEB J 23, 4276- 4287.

Fasanaro, P., D'Alessandra, Y., Di Stefano, V., Melchionna, R., Romani, S., Pompilio, G., Capogrossi, M.C., and Martelli, F. (2008). MicroRNA-210 modulates endothelial cell response to hypoxia and inhibits the receptor tyrosine kinase ligand Ephrin-A3. J Biol Chem 283, 15878-15883.

Fornari, F., Milazzo, M., Chieco, P., Negrini, M., Calin, G.A., Grazi, G. L., Pollutri, D., Croce, C.M., Bolondi, L., and Gramantieri, L. (2010). miR-199a-3p regulates $m$ TOR and $c-$ Met to influence the doxorubicin sensitivity of human hepatocarcinoma cells. Cancer Res 70, 5184-5193.
Friedl, P., and Wolf, K. (2010). Plasticity of cell migration: a multiscale tuning model. J Cell Biol 188, 11-19.

Friedman, R.C., Farh, K.K., Burge, C.B., and Bartel, D.P. (2009). Most mammalian mRNAs are conserved targets of microRNAs. Genome Res 19, 92-105.

Gabriely, G., Wurdinger, T., Kesari, S., Esau, C.C., Burchard, J., Linsley, P.S., and Krichevsky, A.M. (2008). MicroRNA 21 promotes glioma invasion by targeting matrix metalloproteinase regulators. Mol Cell Biol 28, 5369-5380.

Garofalo, M., Di Leva, G., Romano, G., Nuovo, G., Suh, S.S., Ngankeu, A., Taccioli, C., Pichiorri, F., Alder, H., Secchiero, P., et al. (2009). miR-221\&222 regulate TRAIL resistance and enhance tumorigenicity through PTEN and TIMP3 downregulation. Cancer Cell 16, 498-509.

Gregory, R.I., Chendrimada, T.P., and Shiekhattar, R. (2006). MicroRNA biogenesis: isolation and characterization of the microprocessor complex. Methods Mol Biol 342, 33-47.

He, L., and Hannon, G.J. (2004). MicroRNAs: small RNAs with a big role in gene regulation. Nat Rev Genet 5, 522-531.

Huang, Q., Gumireddy, K., Schrier, M., le Sage, C., Nagel, R., Nair, S., Egan, D.A., Li, A., Huang, G., Klein-Szanto, A.J., et al. (2008). The microRNAs miR-373 and miR-520c promote tumour invasion and metastasis. Nat Cell Biol 10, 202-210.

Ji, J., Zhao, L., Budhu, A., Forgues, M., Jia, H.L., Qin, L.X., Ye, Q.H., Yu, J., Shi, X., Tang, Z.Y., et al. (2010). Let-7g targets collagen type I alpha2 and inhibits cell migration in hepatocellular carcinoma. J Hepatol 52, 690-697.

Ji, X. (2008). The mechanism of RNase III action: how dicer dices. Curr Top Microbiol Immunol 320, 99-116.

Jiang, L., Liu, X., Kolokythas, A., Yu, J., Wang, A., Heidbreder, C.E., Shi, F., and Zhou, X. (2010). Downregulation of the Rho GTPase signaling pathway is involved in the microRNA-138-mediated inhibition of cell migration and invasion in tongue squamous cell carcinoma. Int J Cancer 127, 505-512.

Korpal, M., Lee, E.S., Hu, G., and Kang, Y. (2008). The miR-200 family inhibits epithelial-mesenchymal transition and cancer cell migration by direct targeting of E-cadherin transcriptional repressors ZEB1 and ZEB2. J Biol Chem 283, 14910-14914.

Lauffenburger, D.A., and Horwitz, A.F. (1996). Cell migration: a physically integrated molecular process. Cell 84, 359-369.

Lee, R.C., Feinbaum, R.L., and Ambros, V. (1993). The C. elegans heterochronic gene lin-4 encodes small RNAs with antisense complementarity to lin-14. Cell 75, 843-854.

Lee, Y., Kim, M., Han, J., Yeom, K.H., Lee, S., Baek, S.H., and Kim, V. N. (2004). MicroRNA genes are transcribed by RNA polymerase II. EMBO J 23, 4051-4060.

Li, G., Luna, C., Qiu, J., Epstein, D.L., and Gonzalez, P. (2010). Targeting of integrin beta1 and kinesin 2alpha by microRNA 183. J Biol Chem 285, 5461-5471.

Li, N., Fu, H., Tie, Y., Hu, Z., Kong, W., Wu, Y., and Zheng, X. (2009a). miR-34a inhibits migration and invasion by down-regulation of cMet expression in human hepatocellular carcinoma cells. Cancer Lett 275, 44-53.

Li, S., Fu, H., Wang, Y., Tie, Y., Xing, R., Zhu, J., Sun, Z., Wei, L., and Zheng, X. (2009b). MicroRNA-101 regulates expression of the vfos FBJ murine osteosarcoma viral oncogene homolog (FOS) oncogene in human hepatocellular carcinoma. Hepatology 49 , 1194-1202. 
Li, Y., Song, Y.H., Li, F., Yang, T., Lu, Y.W., and Geng, Y.J. (2009c). MicroRNA-221 regulates high glucose-induced endothelial dysfunction. Biochem Biophys Res Commun 381, 81-83.

Lin, S.L., Chiang, A., Chang, D., and Ying, S.Y. (2008). Loss of mir146a function in hormone-refractory prostate cancer. RNA 14, $417-424$.

Ma, L., Teruya-Feldstein, J., and Weinberg, R.A. (2007). Tumour invasion and metastasis initiated by microRNA-10b in breast cancer. Nature 449, 682-688.

Ma, L., Young, J., Prabhala, H., Pan, E., Mestdagh, P., Muth, D., Teruya-Feldstein, J., Reinhardt, F., Onder, T.T., Valastyan, S., et al. (2010). miR-9, a MYC/MYCN-activated microRNA, regulates Ecadherin and cancer metastasis. Nat Cell Biol 12, 247-256.

Meng, F., Henson, R., Wehbe-Janek, H., Ghoshal, K., Jacob, S.T., and Patel, T. (2007). MicroRNA-21 regulates expression of the PTEN tumor suppressor gene in human hepatocellular cancer. Gastroenterology 133, 647-658.

Murchison, E.P., and Hannon, G.J. (2004). miRNAs on the move: miRNA biogenesis and the RNAi machinery. Curr Opin Cell Biol 16, 223-229.

Parent, C.A., and Devreotes, P.N. (1999). A cell's sense of direction. Science 284, 765-770.

Pineau, P., Volinia, S., McJunkin, K., Marchio, A., Battiston, C., Terris, B., Mazzaferro, V., Lowe, S.W., Croce, C.M., and Dejean, A. (2010). miR-221 overexpression contributes to liver tumorigenesis. Proc Natl Acad Sci U S A 107, 264-269.

Poliseno, L., Tuccoli, A., Mariani, L., Evangelista, M., Citti, L., Woods, K., Mercatanti, A., Hammond, S., and Rainaldi, G. (2006). MicroRNAs modulate the angiogenic properties of HUVECs. Blood 108, 3068-3071.

Rana, T.M. (2007). Illuminating the silence: understanding the structure and function of small RNAs. Nat Rev Mol Cell Biol 8, 23-36.

Reddy, S.D., Ohshiro, K., Rayala, S.K., and Kumar, R. (2008). MicroRNA-7, a homeobox D10 target, inhibits p21-activated kinase 1 and regulates its functions. Cancer Res 68, 8195-8200.

Reddy, S.D., Pakala, S.B., Ohshiro, K., Rayala, S.K., and Kumar, R. (2009). MicroRNA-661, a c/EBPalpha target, inhibits metastatic tumor antigen 1 and regulates its functions. Cancer Res 69, 5639-5642.

Ridley, A.J., Schwartz, M.A., Burridge, K., Firtel, R.A., Ginsberg, M.H., Borisy, G., Parsons, J.T., and Horwitz, A.R. (2003). Cell migration: integrating signals from front to back. Science 302, 1704-1709.

Salvi, A., Sabelli, C., Moncini, S., Venturin, M., Arici, B., Riva, P., Portolani, N., Giulini, S.M., De Petro, G., and Barlati, S. (2009). MicroRNA-23b mediates urokinase and c-met downmodulation and a decreased migration of human hepatocellular carcinoma cells. FEBS J 276, 2966-2982.

Scott, G.K., Goga, A., Bhaumik, D., Berger, C.E., Sullivan, C.S., and Benz, C.C. (2007). Coordinate suppression of ERBB2 and ERBB3 by enforced expression of micro-RNA miR-125a or miR-125b. J Biol Chem 282, 1479-1486.

Segura, M.F., Hanniford, D., Menendez, S., Reavie, L., Zou, X., Alvarez-Diaz, S., Zakrzewski, J., Blochin, E., Rose, A., Bogunovic, D., et al. (2009). Aberrant miR-182 expression promotes melanoma metastasis by repressing $\mathrm{FOXO} 3$ and microphthalmiaassociated transcription factor. Proc Natl Acad Sci U S A 106, 1814-1819.
Sehm, T., Sachse, C., Frenzel, C., and Echeverri, K. (2009). miR-196 is an essential early-stage regulator of tail regeneration, upstream of key spinal cord patterning events. Dev Biol 334, 468-480.

Sengupta, S., den Boon, J.A., Chen, I.H., Newton, M.A., Stanhope, S. A., Cheng, Y.J., Chen, C.J., Hildesheim, A., Sugden, B., and Ahlquist, P. (2008). MicroRNA 29c is down-regulated in nasopharyngeal carcinomas, up-regulating mRNAs encoding extracellular matrix proteins. Proc Natl Acad Sci U S A 105, 5874-5878.

Shan, S.W., Lee, D.Y., Deng, Z., Shatseva, T., Jeyapalan, Z., Du, W. W., Zhang, Y., Xuan, J.W., Yee, S.P., Siragam, V., et al. (2009). MicroRNA miR-17 retards tissue growth and represses fibronectin expression. Nat Cell Biol 11, 1031-1038.

Song, H., and Bu, G. (2009). MicroRNA-205 inhibits tumor cell migration through down-regulating the expression of the LDL receptor-related protein 1. Biochem Biophys Res Commun 388, 400-405.

Tavazoie, S.F., Alarcón, C., Oskarsson, T., Padua, D., Wang, Q., Bos, P.D., Gerald, W.L., and Massagué, J. (2008). Endogenous human microRNAs that suppress breast cancer metastasis. Nature 451, 147-152.

Tian, Y., Luo, A., Cai, Y., Su, Q., Ding, F., Chen, H., and Liu, Z. (2010). MicroRNA-10b promotes migration and invasion through KLF4 in human esophageal cancer cell lines. J Biol Chem 285, 7986-7994.

Tsai, W.C., Hsu, P.W., Lai, T.C., Chau, G.Y., Lin, C.W., Chen, C.M., Lin, C.D., Liao, Y.L., Wang, J.L., Chau, Y.P., et al. (2009). MicroRNA-122, a tumor suppressor microRNA that regulates intrahepatic metastasis of hepatocellular carcinoma. Hepatology 49, 1571-1582.

Valastyan, S., Reinhardt, F., Benaich, N., Calogrias, D., Szász, A.M., Wang, Z.C., Brock, J.E., Richardson, A.L., and Weinberg, R.A. (2009). A pleiotropically acting microRNA, miR-31, inhibits breast cancer metastasis. Cell 137, 1032-1046.

Wang, B., Hsu, S.H., Majumder, S., Kutay, H., Huang, W., Jacob, S.T., and Ghoshal, K. (2010a). TGFbeta-mediated upregulation of hepatic miR-181b promotes hepatocarcinogenesis by targeting TIMP3. Oncogene 29, 1787-1797.

Wang, C.H., Lee, D.Y., Deng, Z., Jeyapalan, Z., Lee, S.C., Kahai, S., Lu, W.Y., Zhang, Y., Yang, B.B., and Bähler, J. (2008a). MicroRNA miR-328 regulates zonation morphogenesis by targeting CD44 expression. PLoS ONE 3, e2420.

Wang, G., Mao, W., and Zheng, S. (2008b). MicroRNA-183 regulates Ezrin expression in lung cancer cells. FEBS Lett 582, 3663-3668.

Wang, G., Mao, W., Zheng, S., and Ye, J. (2009). Epidermal growth factor receptor-regulated miR-125a-5p-a metastatic inhibitor of lung cancer. FEBS J 276, 5571-5578.

Wang, X., Hu, G., and Zhou, J. (2010b). Repression of versican expression by microRNA-143. J Biol Chem 285, 23241-23250.

Xia, H., Qi, Y., Ng, S.S., Chen, X., Li, D., Chen, S., Ge, R., Jiang, S., Li, G., Chen, Y., et al. (2009). microRNA-146b inhibits glioma cell migration and invasion by targeting MMPs. Brain Res 1269, 158-165.

Yan, D., Dong, X.E., Chen, X., Wang, L., Lu, C., Wang, J., Qu, J., and Tu, L. (2009). MicroRNA-1/206 targets c-Met and inhibits rhabdomyosarcoma development. J Biol Chem 284, 29596-29604.

Yao, J., Liang, L., Huang, S., Ding, J., Tan, N., Zhao, Y., Yan, M., Ge, C., Zhang, Z., Chen, T., et al. (2010). MicroRNA-30d promotes 
tumor invasion and metastasis by targeting Galphai2 in hepatocellular carcinoma. Hepatology 51, 846-856.

Yu, Z., Willmarth, N.E., Zhou, J., Katiyar, S., Wang, M., Liu, Y., McCue, P.A., Quong, A.A., Lisanti, M.P., and Pestell, R.G. (2010). microRNA 17/20 inhibits cellular invasion and tumor metastasis in breast cancer by heterotypic signaling. Proc Natl Acad Sci U S A 107, 8231-8236.
Zhang, X., Liu, S., Hu, T., Liu, S., He, Y., and Sun, S. (2009). Upregulated microRNA-143 transcribed by nuclear factor kappa B enhances hepatocarcinoma metastasis by repressing fibronectin expression. Hepatology 50, 490-499.

Zhang, Y., Liu, D., Chen, X., Li, J., Li, L., Bian, Z., Sun, F., Lu, J., Yin, Y., Cai, X., et al. (2010). Secreted monocytic miR-150 enhances targeted endothelial cell migration. Mol Cell 39, 133-144. 